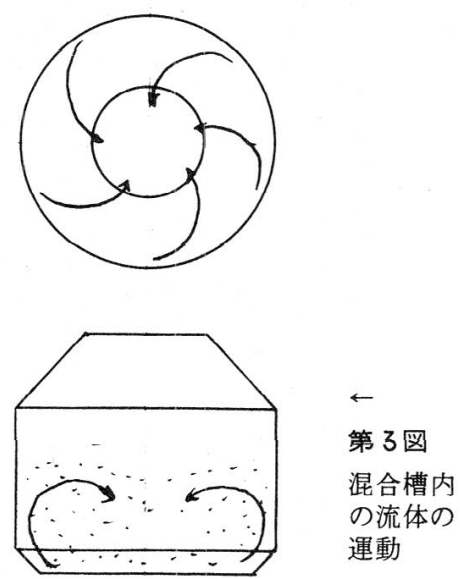

り運動を行なう。したがつて円筒の底部周辺が急速な上下運動を 行ない，この運動が底部円周に沿つて移行する。このため混合槽 内の粉体は次項に記すような運動が与えられ急速混合が行なわれ る。

駆動軸の回転数沙混合盙の大きさにより大体 $400 \sim 800 \mathrm{rp} \mathrm{m}$ 程 度で, 中心軸のゴマ摺り角度 $\theta$ は $10^{\circ}$ 内外である。

\section{3. 混 合 作 動}

混合容器内の粉体は容器の底面および側壁の頻繁な動摇運動に より流動状態となり, 第 3 図の矢印で示すように槽底周辺から中 心に向つて上下対流運動を盛んに行ない，かつ回転移行するので, 混合作用が連続的にむらなく進められる。

このため粒度，比重の極端に異なるものも短時間に混合する。 粉体の装入厚は混合槽の径の $1 / 3$ ないし1/2が適量である。
第 4 図は最も基本的な形状のスーパーミ キサーの一例で説明のために混合槽周りの カバーは取り外ずしてある。粉体を槽上端 の開口部から投入して運転を開始し, 所要 時間後に排出をする。排出は手動または電 動による転倒排出で短時間に完了するが, 槽底の周辺部に自動開閉弁を設けることに より転倒せずに運転のまま全量を排出する ことができて多量処理に好都合である。

混合操作中に追加投入，バインダー等の 液体添加も可能で, 液体添加にはスフンー ノズルを利用することが最適である。混合 に要する時間は 0.5 分ないし 2.0 分で十分 である。

本機の特徵利点を要約すると次の通りで

ある。

(1) 機構が簡単で故障がない。所要動力が少ない。

(2) 混合能力が抜群で比重, 粒度, 形状の差異の大小にかかわ らず完全混合が達成される。底部弁装置により運転を継続しつつ 排出できるので偏析を起こし易いものも完全混合状態で取り出せ る。

(3) 混合所要時間が非常に短かくてすむ。

（4）投入，排出操作が簡単でこれに要する時間が少ない。

（5）投人，混合，排出の一連の操作を自動化することができる。

（6）運転中に追加投入が可能である。

（7）槽内に障害物がないので清掃が容易に完全に行なわれる。

（8）加熱, ガス吹込み等の装置の装着が可能である。

本稿製作の時点では各種テストおよび実績のデータの取りまと め中であるため簡単な説明に止どめたが, 改めて参考に供せるよ うな報告を行ないたい。

\title{
4. 操作および特徴
}

\section{[記 念 講 演]}

（3）幌内選炭工場の概要について

\section{1. まえがき}

幌内炭鉱は昭和 50 年 11 月 27 日未明, 七片地並 ( S. L. - 1,000 m)において発生したガス爆発による坑内火災消火のため, 13 名の遺体を残したままほぼ全山水没の止むなきに至つた。 その後復旧作業に全力をつくし, 昨年 10 月より取明作業と並 行して生産再開に漕ぎつけ, 逐次予定の出炭を確保しつつ全面復 旧に向つて鋭意努力中である。

およそ 2 年間に亘る生産ストップにより需要先に対する供給不 能, 経済不況, 販路の失地饭復, 51 年 6 月以降坑廃水 $150 \mathrm{ppm}$ 規制等生産再開後の環境はまことに厳しいが，これらの諸問題と 取組んでいる幌内選炭工場の概要について報告する。

\section{2. 晩内炭鉱概要}

当炭鉱は北海道のほぼ中央三笠市に位置し, 明治 12 年 国営で 開坑，同 22 年 当社が払下げを受け今日に至つている。
出炭は災害前日産 $4,740 t$ の実績で, 完全復旧後の 54 年度 以降 の目標出炭は日産 4,500 tである。

鉱区は夕張炭田の北端で幾春別炭田とも呼ばれ, 地質は白亜紀 層を基盤に古第三紀石狩層群その上部に幌内層群により構成され ている。

当区域では石狩層群の内幾春別層だけが発達し, これを被覆す る幌内層は厚く緻密な泥岩層で, このため坑内では地表水の浸入 が少なく，メタンガスの発生が多いことが特徵となつている。

幾春別層は層厚およそ $300 \mathrm{~m}$ で十数枚の炭層をもつているが, 稼行対象となるのは第 1 四に示す五番上層, 五番層, 四番上層, 四番層, 三番層, 前層および一番層の七層である。

炭質は不粘結性浱青炭でいわゆる「讶元物」として代表的な一 般炭である。

現在六片地並 (S.L. $-860 \sim-930 \mathrm{~m}$ 間) を採掘し, 坑内から の原炭搬出は全てベルトコンベヤシステムで, その総延長は復旧 途上の現在およそ $6,600 \mathrm{~m}$ である。

$700<4>$ 


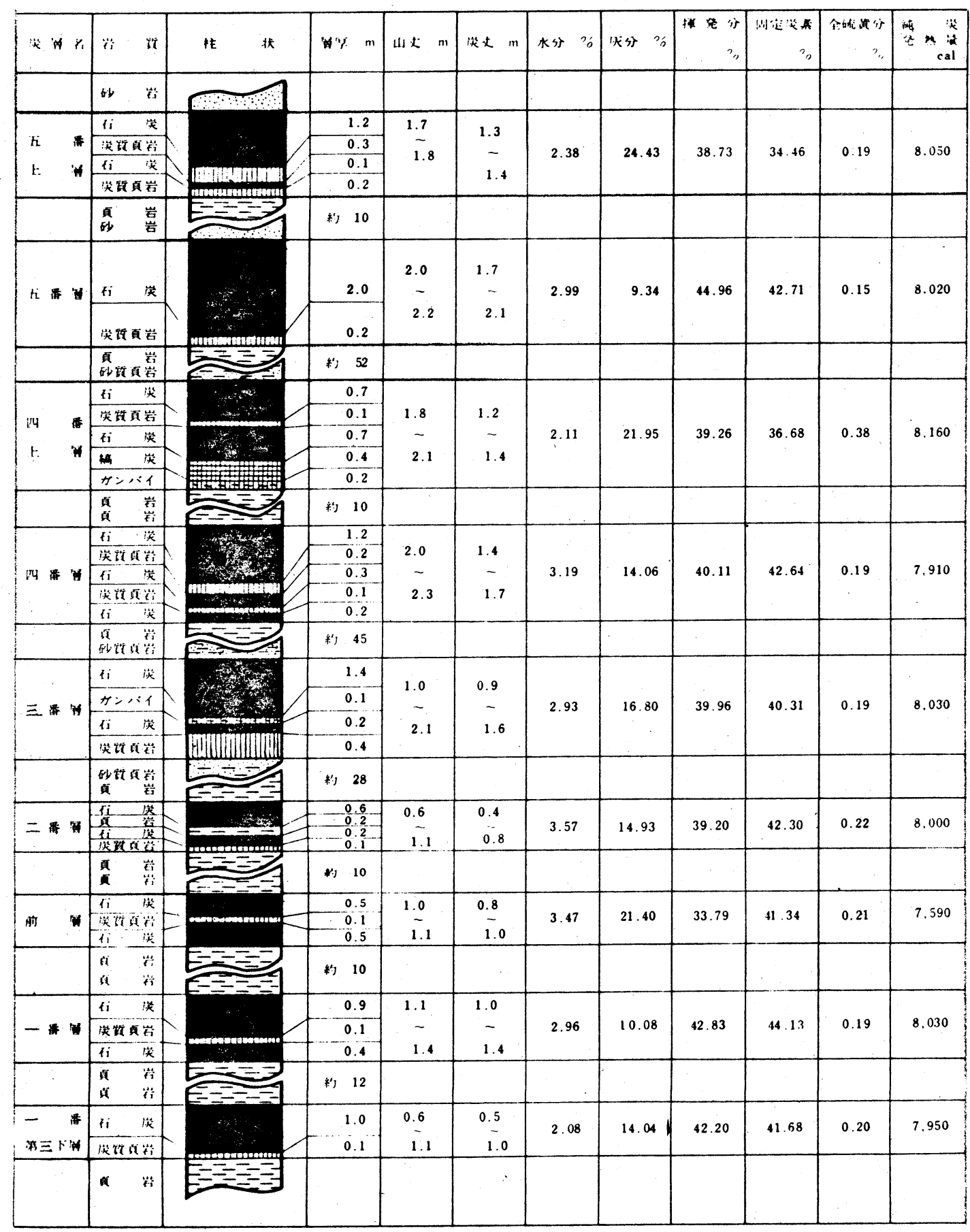

\section{3. 選炭工場概要}

選炭工場は国鉄三笠駅より $2.7 \mathrm{~km}$ の幌内線の終点幌内駅より専 用線で $0.8 \mathrm{~km}$ の位置で, 幌内川支流本沢川の川岸丘陵地で周りが 山地に囲れた狭小な環境 (第 2 図)の中にあり, 揚炭常盤斜坑坑 ロより $90 \mathrm{~m}$, 沅内立坑との距離はおよそ $2.5 \mathrm{~km}$ の位置にある。

工場のフロシートは第 3 図の通りで一般炭選炭工場の通例とし て至つて複雑である。

主要選炭設備および産出精炭銘柄については第 1 表および第 2 表に示す。

\section{$3 \cdot 1$ 重選系統}

「讶え物」炭の代表銘柄として+25 mm塊炭類の選別はマグネ タイトを重質としてドルボーイ式重選機（昭和 35 年 9 月 稼働開
始 ) で操業, 原炭を乾式 $25 \mathrm{~mm} \phi$ でふるい分け+ $25 \mathrm{~mm}$ 原炭を主 選重液比重およそ 1.34 ，再選 1.72 で選別する。

重選操業開始当初は一号物塊炭類の精炭割合が $40 \%$ 近くの塊率 を占めていたが，その後坑内稼行現場の深部化および機械化採炭 移行につれて原炭の粉化現象が進み, 最近では塊率 $18 \%$ 前後と 従来のおよそ $50 \%$ 程度に低下している。

加えて年々一般暖房用炭シェアが油に転換されて需要減を招き, 折角の塊炭類をクラッシニの止むなき状態に移行している。

マグネタイト消費量も稼行炭層，原炭粉分および水分等の諸条 件により, 乾式ふるいのふるい効率低下を来たし原炭 $\mathrm{t}$ 当り 350 $\sim 800 \mathrm{~g}$ と幅広い変動を示している。

\section{$3 \cdot 2$ 水選系統}

$-25 \mathrm{~mm}$ 粉原炭は稼行炭層組合せによつて変動幅大きいが概し 


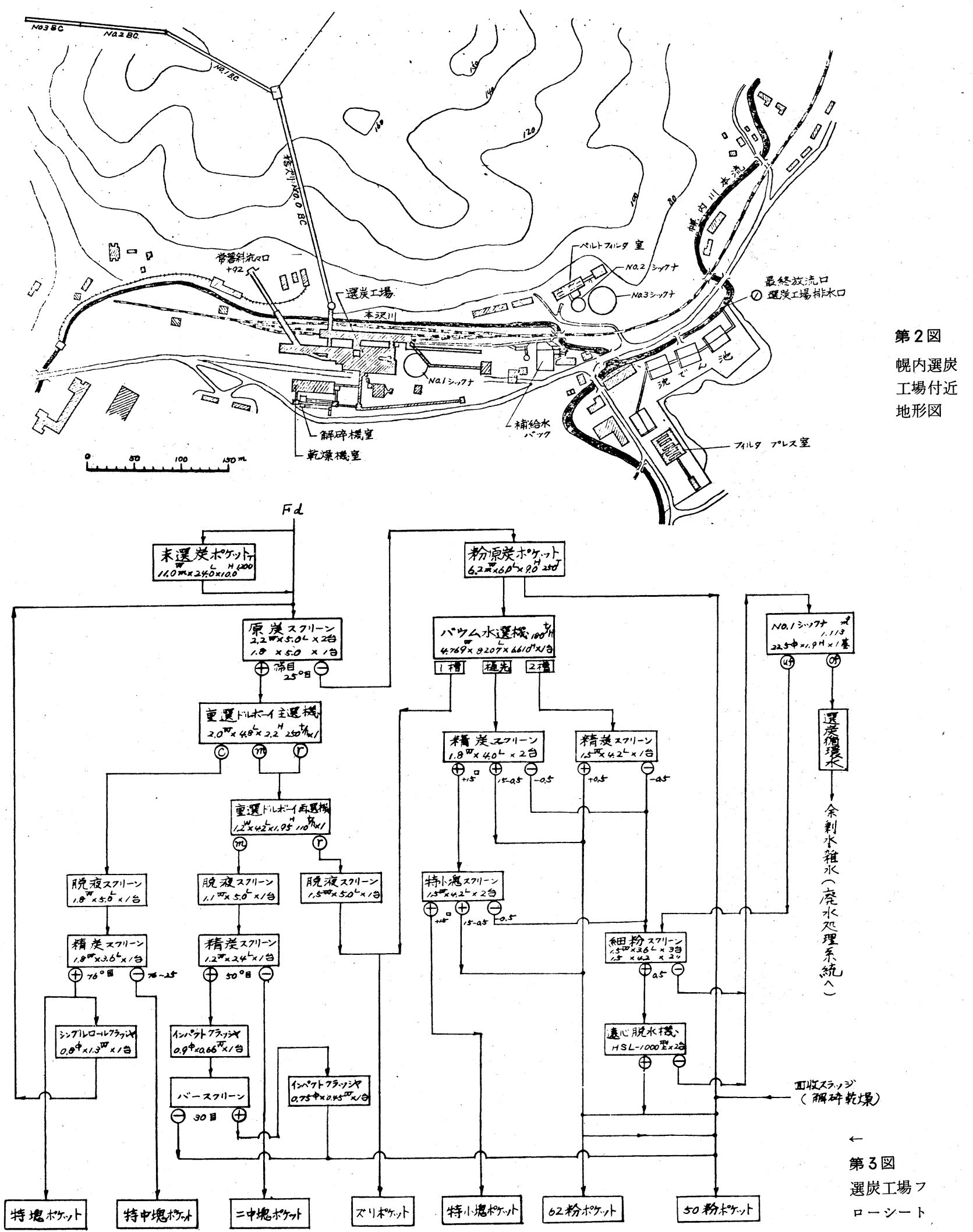

\section{て可選性は良好である。}

水選機はバウム $180 \mathrm{t} / \mathrm{h} 1$ 基操業中である（昭和 43 年 8 月ま でレオ水選機, 43 年 9 月以降 $180 \mathrm{t} / \mathrm{h}$ バウム 1 基とレオ水選機 1 系統, 48 年 6 月 以降バウム 1 基の操業となる。)。

一般用粉炭の生産銘柄はその時々の市場要請に対応し数多くの 銘柄を生産してきた(ここ数年間で 9 銘柄に及んだ。)。 従来粉炭の大口需要先は揚地電力用として全出炭の $45 \%$ 程度
が納炭されていたが，都市環境公害規制強化につれ逐次重油転換 が行なわれ, 昭和 47 年頃から徐々に需要が下降を辿り昭和 48 年 度以降 20〜25\%量と半減した。

この打開策として昭和 47 年度より北電向け 50 粉生産に踏切り, その生産量はおよそ $35 \%$ に達している(第 3 表)。

フロシートのとおり未選粉を主体とする 50 粉 生産方式に切替 えたことにより水選機はバウム 1 基の操業となる。 
第 1 表 主要選炭機械設備表

\begin{tabular}{|c|c|c|c|c|c|c|}
\hline 番号 & 機械名称 & 主要寸法 & $\begin{array}{l}\text { 公称 } \\
\text { 能力盾 } \\
\end{array}$ & $K W$ & 台数 & 備 \\
\hline 1 & 原崖スクリーン & $2,200^{W} \times 5.000^{2}$ & 500 & 19 & 2 & 緗目 $25 \phi$ \\
\hline 2 & $\| \quad x>11-\nu$ & $1.800 \times 5.000$ & 300 & 15 & 1 & $"$ \\
\hline 3 & 重選けルボーイ主邆㭜 & $2,000 \times 4,000 \times 2,200$ & 250 & $\begin{array}{l}3.7 \\
3.7\end{array}$ & 1 & $"$ \\
\hline 4 & 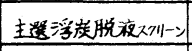 & $1.000 \times 5.000$ & 145 & 15 & 1 & 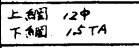 \\
\hline 5 & " 洗浮ススリン & $1.800 \times 3.600$ & 150 & 15 & 1 & \begin{tabular}{|l} 
上細算 764 \\
F細 104 \\
\end{tabular} \\
\hline 6 & 裏選トルボーイ再選機 & $1.200 \times 4.165 \times 1.850$ & 110 & $\begin{array}{l}22 \\
1.4 \\
\end{array}$ & 1 & \\
\hline 7 & 再選浮岸脱液スフリーン & $1.100 \times 5.000$ & 25 & 15 & 1 & 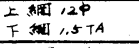 \\
\hline 8 & " 洗淨羽1- & $1.200 \times 2.400$ & 50 & 11 & 1 & 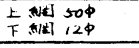 \\
\hline 9 & 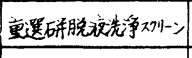 & $1.500 \times 5.000$ & 150 & 15 & 1 & $\begin{array}{ll}\text { 上細 } & 12 \phi \\
\text { 細 } & 1.2 T A \\
\end{array}$ \\
\hline 10 & 重選絸下スフリーン & $1.200 \times 3.600$ & 15 & 15 & 1 & 粗目 $0,25 T A$ \\
\hline 11 & 一次磁遇機 & $1.200 \times 600 \phi$ & 14 & 1,5 & 2 & \\
\hline 12 & 二次磁選機 & $1.200 \times 600 \phi$ & 14 & 1.5 & 1 & \\
\hline 13 & 特塊シンダレローレフラジメ & $000^{4} \times 1.300$ & 80 & 60 & 1 & \\
\hline 14 & 亚塊インパフトフラッシ・ & $900^{4} \times 660$ & 15 & 15 & 1 & \\
\hline 15 & 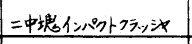 & $750^{\phi} \times 450$ & 10 & 15 & 1 & \\
\hline 16 & バウム水選識 & $4469 \times 8.207 \times 6610$ & 180 & $\begin{array}{r}15 \times 2 \\
3.7 \\
\end{array}$ & 1 & $\nabla 6372+2$ \\
\hline 17 & 精定口-ヘ・午スフリーン & $1.800 \times 4.000$ & 90 & 15 & 2 & 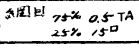 \\
\hline 18 & 二槽金物 “ & $1.500 \times 4.200$ & 90 & 15 & 1 & $" \quad 0.5 \mathrm{TA}$ \\
\hline 19 & 特小地 & $1.500 \times 4.200$ & 30 & 15 & 2 & 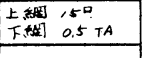 \\
\hline 20 & 細粉 & $1.500 \times 3.600$ & 20 & 11 & 3 & 解目 $\quad 0.5 T A$ \\
\hline 24 & No.1 $\equiv \ldots, 7+$ & $22,500^{\phi} \times 1.900$ & 1,13 & 5.5 & 1 & \\
\hline 22 & 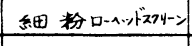 & $1.500 \times 4.200$ & 20 & 15 & 2 & 细目 $0.5 T \mathrm{~A}$ \\
\hline 23. & 遠心脱水栈 & HSL-1000 型 & 60 & $\begin{array}{l}22 \\
3.7 \\
0.4 \\
\end{array}$ & 2 & \\
\hline 24 & 選炎水推珢㛫ンプ & $S P L-200 \mathrm{C}$ 型 & 10.2 & 100 & 11 & \\
\hline & & & & & & \\
\hline
\end{tabular}

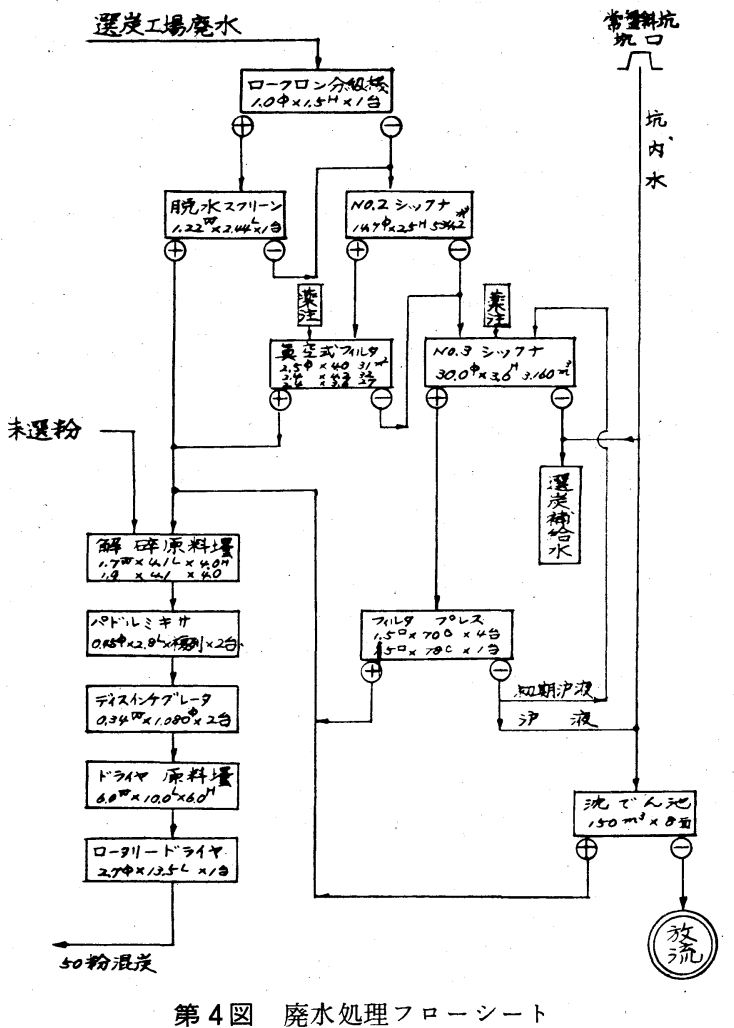

水選精炭の脱水ふるい下として発生する粒度 $0.5 \mathrm{~mm}$ 程度の細 粉は遠心脱水機で脱水後, 揚地電力向 62 粉または 50 粉品位調整 用として混炭している。
第 2 表 銘柄別保証品位および工業分析表

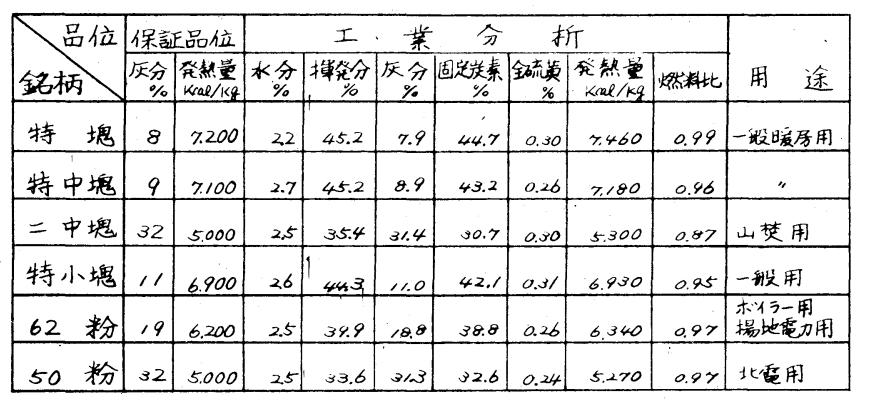

第3表 年度別揚地電力用および北電用納炭推移対比表

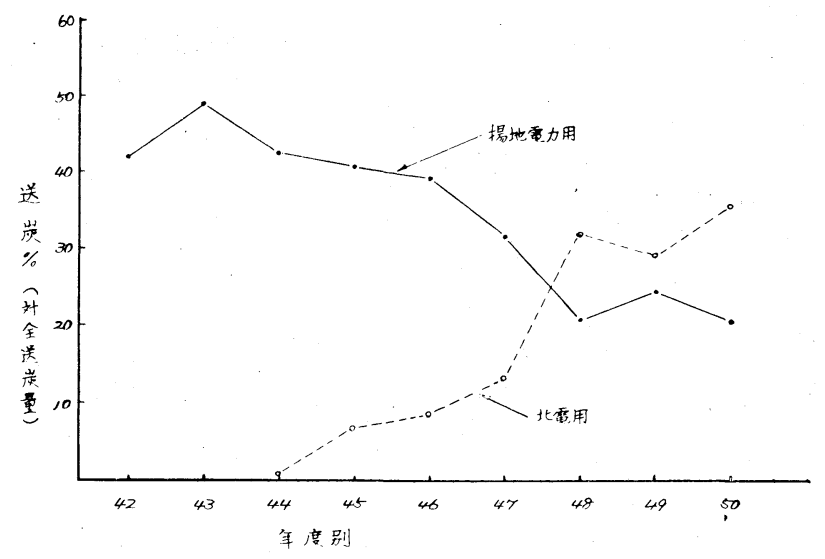

第 4 表 主要廃水処理機械設備表

\begin{tabular}{|c|c|c|c|c|c|c|}
\hline 番号 & 機械名称 & 主要才法 & \begin{tabular}{|r|} 
TA \\
公秝能力 \\
\end{tabular} & $k w$ & 台数 & 储 \\
\hline 1 & ㅁ 7 口 & $1.000 \phi_{x} 1,500$ & $0.8 r^{m^{2}}$ & & 1 & \\
\hline 2 & 三微㸮スクリーン & $1.220^{\mathrm{W}} \times 2.440^{\mathrm{L}}$ & 10 & 5 & 1 & 組且 0.5 \\
\hline 3 & №. $2 シ ッ 7+$ & $14.700^{4} \times-500$ & $\begin{array}{r}m^{3} \\
534.2 \\
\end{array}$ & $\begin{array}{l}3.7 \\
0.7 \\
\end{array}$ & 1 & \\
\hline 4 & 凝臬到一次溶的措 & $\begin{array}{l}1,450 \phi \times 1300 \\
1.500 \phi \times 1,500 \\
\end{array}$ & $\begin{array}{l}2.25 \\
2.65 \\
\end{array}$ & $\begin{array}{l}0.75 \\
2.2 \\
\end{array}$ & 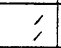 & \\
\hline 5 & 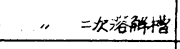 & $\begin{array}{l}2.1009 \times 2.100 \\
2,5004 \times 2,500 \\
\end{array}$ & $\begin{array}{l}7.28 \\
12.2 \\
\end{array}$ & $\begin{array}{l}2,2 \\
2,2 \\
\end{array}$ & $\begin{array}{l}1 \\
3 \\
\end{array}$ & \\
\hline 6 & No./ベルトフイルタ & $2.400 \phi^{4} \times 4.200$ & 6.0 & $\begin{array}{l}1.5 \\
2.25 \\
0.75 \\
\end{array}$ & 1 & \\
\hline 7 & No.2 " & $2.5009 \times 4.000$ & 6.0 & $\begin{array}{r}1.5 \\
2.22 \\
0.25 \\
\end{array}$ & 1 & 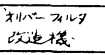 \\
\hline 8 & ro.3オルーバ スネタ & $2.4009 \times 3.600$ & 5.0 & $\begin{array}{l}3.7 \\
0.7\end{array}$ & 1 & \\
\hline 9 & No. $3 \equiv \cdots 7 t$ & $30.000^{\phi} \times 3.600$ & 3.160 & 7,5 & 1 & \\
\hline 10 & フィルタープレス & $\begin{array}{l}71195 M F-18 \\
1,500 \times 70^{\circ}=1\end{array}$ & $\frac{m^{2}}{2 \pi 2,2}$ & $\begin{array}{c}1.5 \\
0, \times 2\end{array}$ & 4 & \\
\hline 川 & " & $\begin{array}{l}\text { 日本码子 } 3 \text { NR4-PF } \\
1500^{\circ} \times 78 \text { \& } \\
\end{array}$ & $295^{m^{2}}$ & $\begin{array}{l}1.5 \\
0.1\end{array}$ & 1 & \\
\hline 12 & 沈でん池 & $4.000 \times 12000 \times 1.200$ & $150^{m^{4}}$ & & 8 & \\
\hline 13 & パドルミキ\# & $400^{\phi} \times 2800 \times 1 \times 1810$ & 50 & 7,5 & 2 & \\
\hline 14 & ディスインデブレータ & $340^{m} \times 1000^{d}$ & 40 & $37 \times 2$ & 2 & \\
\hline 15 & $\mp ー フ ゙ ル フ フ_{1}-8^{\prime}$ & $\begin{array}{l}\text { 上 } 15000 \\
F 1,9004\end{array}$ & 20 & \# & 1 & \\
\hline 16 & ローヌリードライャ & $2.7009 \times 10.500^{77 m^{4}}$ & 20 & 50 & 1 & 䋅数 PIC \\
\hline 17 & 然炶用送几枉 & $150 \mathrm{~m} / \mathrm{mm} \times 360 \mathrm{~mm}$ & & 22 & 1 & \\
\hline 18 & 稀积用送见格 & $450 \mathrm{~m} / \mathrm{m} / \mathrm{min} \times 50^{\mathrm{m}} \mathrm{As}$ & & 11 & 1 & \\
\hline 19 & 主排几栦 & $620 \mathrm{~m} / \mathrm{mm} \times-750 \mathrm{mo}$ & & 50 & 1 & \\
\hline 20 & 乾式果に械 & $\begin{array}{l}+1700 \\
2.200 \phi \times 1.950\end{array}$ & & & , & \\
\hline 21 & 愍式某心栈 & 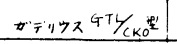 & oratim & & 1 & \\
\hline
\end{tabular}

一般用粉炭の安定需要先として昭和 55 年度 操業予定の北電厚 真発電所の発電開始に大きな期待をかけているところである。 $3 \cdot 3$ 微粉処理について

微粉炭の浮選操業は昭和 49 年 5 月 まで国鉄機関車用煉炭原料 として精選微粉およそ $65,000 \mathrm{t} /$ 年 の需要があり,これに対応し 
てダイスターテーブル，デンパー型浮選機による精選操業を行な い, 精細粉 $15 \% \mathrm{~A}, 6,500 \mathrm{cal}$, 上微粉 $14 \% \mathrm{~A}, 6,600 \mathrm{cal}$ 銘柄 の生産供給をつづけた。

しかし国鉄合理化で機関車のジーゼル，電化に伴い廃水処理上 の問題もあり昭和 49 年 6 月以降浮選操業を廃止した。

\section{4. 廃水処理の概要}

坑廃水の排出基準は昭和 47 年以降段階的に規制強化され，51 年 6 月以降最終規制值 $150 \mathrm{ppm}$ が実施された。

これに対処する設備は年々強化され最終的には災害復旧中の 51 年 6 月全工事の完成をみた。

廃水処理 フロシートは第 4 図, 主要機械設備は第 4 表に示す。

当鉱の廃水処理は立地条件, 既設設備, 廃水およびスラッジの

性状等を勘案し，ベルトフィルタとフィルタプレスの組合せによ

り廃水の清澄化に努め, 最終No. 3 シックナのOF を選炭補給水 に使用する完全循環方式を採用した。

精炭および廃石付着水の不足水量は, 補給水バックの水位検出 により自動的に坑内排水より補う方式とした。

設備にあたつて基本方針として，

(1) No. 1 浄化ジックナ濃縮微粉を脱水ふるいで極力回収し， OF の濃度低下につとめ廃水処理系統の負荷軽減を図る。

(2) No. 2 シックナスラッジのベルトフィルタによる回収を強 化し,フィルタプレスの負荷軽減を図る。

(3) フィルタプレスの効率的操業運転と人員節减をねらい, プ レス 5 台の連合運転方式を採る。

(4) 用水の完全循環に対処しNo. 3 シックナOFのSS 安定化。

(5) 各ブロック間の密接な連絡, 連繫と円滑な運転操業を期す。 以上の諸項目に特に重点をおき設備強化を実施した。 昨年 10 月生産再開後の出炭経過を示すと, (期間平均日産)

\begin{tabular}{r|r|r|r}
\hline \multicolumn{1}{c|}{ 間 } & 原炭量· $\mathrm{t} /$ 日 & 出炭量 $\mathrm{t} /$ 日 & 選炭歩留\% \\
\hline $10 \sim 11$ 月 & 2,290 & 1,280 & 55.8 \\
$12 \sim 3$ 月 & 3,960 & 2,580 & 65.1 \\
$4 \sim 6$ 月 & 4,510 & 3,120 & 69.2 \\
\hline
\end{tabular}

以上のようにほぼ予定通りの出炭を確保しつつ全面復旧に邁進 しているが，再開直後の廃水処理操業上の難点をあげると，

i）原炭に揚水後の取明ズリ混入し，スラッジの粘土質分多く ベルトフィルタ，フィルタブレスともに影響を受けた。例えばフ レスの 1 サイクルに 200〜250分の沪過時間を要した。

ii）およそ 2 年の空白があつたため熟練運転工が離山し，再開 と同時に新規採用者の教育訓練から手掛けることになつた。

しかし再開後の出炭が日産 1,000 七ベースから徐々に増えてきた 経過に助けられ, 所期の目的を達成しつつ順調に操業をつづけて いる。 52 年 10 月操業再開以来 6 月までのNo.3 シックナ OFの S S を第 5 表に示す。

\section{5. 回収スラッジの処理について}

廃水処理回収スラッジの処理は第 4 困に示す如く解碎処理後, 坑内ガス利用のロータリードライヤで乾燥, 品位調整の上50粉に 混炭し精炭として再生する方式を採つた。

誘導坑内ガス濃度の関係上ドライヤの運転操業再開は 8 月末の
第 5 表 No. 3 シックナOFのSS 濃度実績表

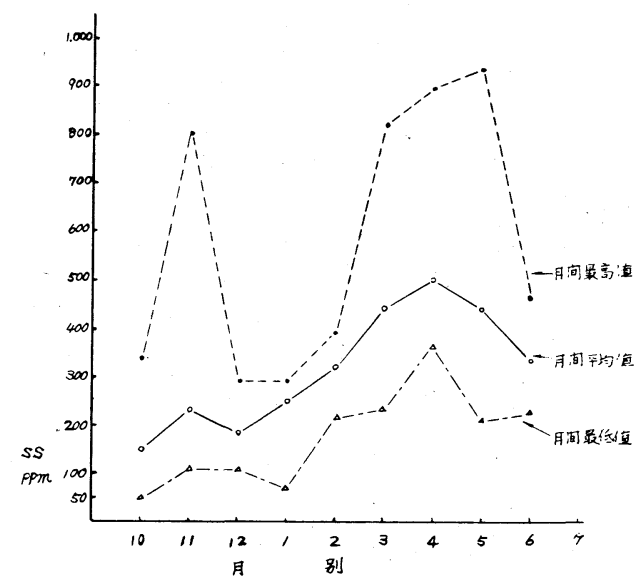

見込である。したがつて現在 50 粉 の大口需要先北電の粉炭水分 許容値内に納まる線を狙つて, 解砕処理後未乾燥のまま混炭中で ある。

$4 \sim 6$ 月日産 3,120 t ベース時のスラッジ回収量は $137 \mathrm{t} /$ 日で (ベルトフィルタ $19 \mathrm{t} /$ 日, プレスケーキ118 t/日), このうち $50 \sim 60 \mathrm{t} /$ 日を処理混炭し残余のケーキは貯炭している。

プレスケーキは粘土質板状の塊りで単味解砕はむずかしい, 現 在ブレスケーキと末選粉の比率 50:50または $40: 60$ 程度で処 理しているが, 処理後のペレット状況から判断して十分精炭とし て再生することが可能である。

ケーキ処理の場合その難易性はヶーキ粒度, 粘土質分（灰分）, 付着水分等に大きく影響される。操業後数少ない試験結果で断定 的なことはいえないが，粒度は+ $0.044 \mathrm{~mm}$ が $20 \mathrm{wt} \%$ ，灰分 $55 \%$ ， $3,000 \mathrm{cal}$, 付着水分 $22 \%$ より良い品質の維持をすれば, 解砕処 理がスムーズに実施可能である。

以上の想定に基づき全体的な処理能力を勘案しつつ, ベルトフ ィルタのフィード原液をブレス原液に混入し, プレス沪過時間, 処理量, ケーキ水分, 粒度構成, 品位, 解砕処理難易度等の変化 を究明すべく操業試験を実施中である。

一方混炭による派生的なトラブルとして, 50 粉貨車積ポケット の積込口付着およびブリッジ現象による積込抜炭不良が発生して いる。

この対策として解砕炭のポケット内偏積防止, ポケット抜口の 断面拡大改造等種々の改善を実施し, 所期の目的達成に努力して いる。

$$
\text { 6. あ がき }
$$

以上甚だ簡単であるが, 幌内炭鉱の選炭工場概要を報告した。 とりわけ坑廃水規制 $150 \mathrm{ppm}$ 強化に対処し, その対策には巨額 な設備投資と莫大なランニングコストを必要とするに鑑み, 資源 の有効利用という見地からスラッジの再生に取組んでいる。

出炭再開後日未だ浅く, 復旧途上で未完のものであるが, 現在 または将来の指針として関係各位の御教示を戴ければ誠に幸とす るところである。 